\title{
Development Strategy and Political Suggestions of Utilizing Foreign Direct Investment in Modern Service Industries in Wuhan
}

\author{
Du LV \\ Huaxia Institute, Wuhan University of Technology, Wuhan, P.R.China, 430070 \\ windlvdu1982@126.com
} Keywords: Modern Service Industries, Political Suggestions, Policy Advice, Foreign Direct
Investment

\begin{abstract}
With the rapid progress of the society, economy, technology and rapid development of the information technology, knowledge economy, the social division is increasingly refinement and specialization, new technology and new mode of modernization is and has services from traditional way for the transformation of knowledge intensive, high value-added, low resource consumption of modern service industry. Wuhan City in Central China, its superior geographical conditions, traffic conditions and river conditions make it become an important commercial center of central china. The development of modern service industry is very important for the economic growth in $t$ Wuhan. This paper puts forward relevant political suggestions to promote the development of modern service industry utilizing foreign capital of Wuhan City on the basis of SWOT analysis.
\end{abstract}

\section{SWOT Analysis of Utilizing FDI by Wuhan Modern Service Industries}

\section{Strengths}

(1) Foreign direct investment in Wuhan gradually concentrating to the third industry

Foreign direct investment in Wuhan mainly concentrated in the second industry, but with the restructuring of China's economic and industry since 1990s, foreign has a promotion in Wuhan third industry and the third industry has become the new focus of foreign direct investment. The absolute scale of attracting foreign capital in Wuhan third industry will continue to grow, but the relative scale to exceed second industry.

(2)Source increasingly diversity of the utilization of foreign direct investment in Wuhan

In 1990s, Asia, especially Hong Kong and Taiwan, has been the most important source attracting foreign direct investment in Wuhan. But in recent years, considering the great influence of the regional and international situation unrest on foreign direct investment, the Wuhan city government adopted a attracting foreign investment strategy of diversity of investment body, increased foreign investment in Europe and America, so that after 2000 the Wuhan changed the past situation depending on Hong Kong and Taiwan area, foreign direct investment from Europe and America became the main part utilizing foreign direct investment.

(3)Gradually change of the pattern of utilizing foreign direct investment into wholly foreign investment enterprises in Wuhan

In the actual foreign direct investment, each year there are fluctuations in wholly foreign investment enterprises and Chinese - foreign cooperative enterprises' share, but wholly foreign-owned enterprises' share was significantly higher than that of Chinese-foreign cooperative enterprises' share. Along with the foreign investment environment was further improved, more and more wholly foreign - investment enterprises established in Wuhan instead of Chinese-foreign cooperative enterprises.

\section{Weaknesses}

Since the reform and opening up Wuhan City has made great achievements in utilizing foreign direct investment, playing a positive role on economic growth, the idea renewal and quickening the 
pace of reform and opening-up, but Wuhan City still exist face on many problems in utilizing foreign direct investment.

(1) Slow growth in utilizing foreign direct investment

Since the past ten years, in Wuhan City, FDI has been on a steady growth trend, from the absolute number, the performance on attracting foreign direct investment has been very impressive, but compared with Suzhou, Shanghai and other city there has been a large gap.

(2) Comprehensive environment improved in utilization of foreign direct investment

Although infrastructure, service level of Wuhan City in the past few years have been improved, there are still problems on some specific steps and the specific procedures such as low efficiency, charging excessive, poor credibility and so on, so that foreign investment's costs increase; Wuhan local industries cannot keep up with foreign investment enterprises, and coordinate production capacity poorly, limiting the expansion of the foreign investment enterprises' reproduction.

\section{Opportunities}

(1)Foreign direct investment increased continually

Analysis statistics in foreign direct investment of Wuhan from 2004 to 2013, it is found that in Wuhan City the actual use of foreign direct investment totally continue to increase.

(2)Increasing direct investment in Wuhan from Multi-National Corporation

In the world's top 500 companies, BP's PP, American Cummings, Japan Teng bin have entered, and Japanese NEC, American Budweiser, French Valeo, Sagem have expand direct investment, there have been 55 enterprises' funds from the world's top 500 companies in Wuhan.

\section{Threats}

(1)Unreasonable structure of foreign direct investment affecting the utilization of foreign capital quality and benefit

First, capital source structure of FDI is not reasonable. Foreign direct investment in Wuhan from developed countries' Multi-National Corporation's investment is not as the main body, instead of from Hong Kong, Macao and Taiwan, direct investment in developed countries are comparatively small. Secondly, main body structure in the foreign direct investment is not reasonable. The main body of Wuhan foreign direct investment is mainly small and medium enterprises from developing countries and regions, instead of large Multi-National Corporation from developed countries. Thirdly, industry and industry structure of FDI is not reasonable. Foreign direct investment is still mainly concentrated on labor-intensive manufacturing and processing industries, instead of urgently developed agriculture, infrastructure and basic industries, high-tech industries and emerging industries, and the level of 1 direct investment on service industry times is lower, mainly in real estate and entertainment industry. The above condition adversely affects the overall quality and effect o on utilizing foreign direct investment in Wuhan.

(2)Low overall technical content

By short-term interest driven factors, most small and medium-sized customers invest Wuhan, in low technology projects of low investment, short cycle, not in the international advanced level project. There are only 59 companies in the world's top 500 companies investing in Wuhan, while the global Multi-National Corporation has 6.3 vanguard, Multi-National Corporation investment has accounted for nearly $90 \%$ of global direct investment, Multi-National Corporation's expansion in recent years has become a main channel of industry grades, there are many problems in attracting Multi-National Corporation investment in Wuhan. Promoting effects on economy has not been fully reflected. 


\section{Strategic thinking on accelerating the development of modern service industry in Wuhan}

\section{Policy innovation}

In order to speed up the development of modern service industry in Wuhan city, the government should take relevant measures to support the modern service industry, and in some ways even should combine with the local legislative power of Wuhan City and build excellent platform in order to attract investment, attract talent and absorb technology in the form of legislation to clear related industry right, taking comprehensive reform area of "two type society" and comprehensive reform area of service as an opportunity.

\section{Opening market}

On one hand, Wuhan city should play fully the role of market mechanism, adhering that the opening up promotes the development and the development seeks the opening up. Wuhan city according to marketization, industrialization, socialization, should further promote the service industries' system reform, deepen the monopoly industry, public utilities and state service enterprises' reform, and relax market access management services. On the other hand, Wuhan city should encourage the full competition, establish fair, fair market environment, crack down on all kinds of anti-competitive practices, through the market mechanism $t$ rationally allocate resources.

\section{The human resources}

Research shows that there is great relation between financial input in education, scientific research and overflowing of high - end training. However, statistical data shows, in Wuhan city financial input in education, scientific research far less than in Beijing and Shanghai. Therefore, Wuhan city's financial input must increase the investment on education and scientific research, and take this as an opportunity, creating a favorable external environment to keep local high-quality and high skilled talents and strengthening the competitiveness in attracting foreign talent.

\section{Policy recommendations further promoting the use of foreign direct investment in Wuhan}

\section{Making full use of the advantages of the existing Wuhan City, to expand the utilization of foreign direct investment}

Compared with other city, in Wuhan there are four obvious comparative advantage: one is the economic geographic location and market distribution advantages: Wuhan is in the center of China, at the intersection of the vertical and horizontal transportation, the capital of Henan, Hunan, Jiangxi, Anhui four province and the Three Gorges area located in the Yichang are in the $500 \mathrm{~km}$ within the scope of. In the long run, Wuhan is very likely to become the biggest inland economic, financial and trade center. Two is the natural resources and industrial advantages: Wuhan with the advantageous conditions for agricultural production and rich water resources, known as "the province of a thousand lakes"; owns 33 kinds of minerals, 154 occurrences, the potential economic value of about 840 billion Yuan; otherwise Wuhan owning whole industrial system, the large number of industries, strong industry relationship, has formed a metallurgical, machinery, automotive, textile, food, chemical, pharmaceutical, building materials and other leading industries. Three is the talent, technology advantages. In Wuhan Science and technology education are developed, with 35 universities, 736 institutes, 10 national key laboratories, 450000 science and technology talent, national leading position in communication, biological engineering, microelectronics, laser technology and new material level, and comprehensive strength in science and technology are in third after Beijing and Shanghai, especially the East Lake High-Tech Development Zone Beijing is second only to Science and Technology Industrial Park of Beijing Haidian, named as "China Silicon Valley". Four is the advantages of basis of industrial economy. Wuhan is the old industrial base, with strong industrial base, and strong comprehensive capacity. It is not unusual for a city to own respectively regional market, the strength of science and education 
and natural and human resources, moreover it is not often to owing all those potential. That make Wuhan occupy a favorable position in the competition of domestic and international market in order to seek industrial competitive advantage and economic advantage, where is the advantages and potential in the development of high-tech industries and modern service industry in Wuhan.

\section{To adopt a flexible and effective way of using foreign capital, encouraging the Wuhan city enterprises strategic alliances with foreign}

Strategic alliance provides technology, information, market share and so on, achieving long-term stable cooperation, which is an excellent choice for Wuhan city to utilize of foreign direct investment. Through the strategic alliance, on the one hand foreign merchants could find partners familiar with Wuhan and China market conditions, reducing foreign investment uncertainties in Wuhan, which can inspire the enthusiasm of foreign investment; On the other hand for Wuhan City enterprise it is convenient to introduce and develop the international market, therefore it is a realistic approach to use external use of foreign direct investment and accelerate the economic development in Wuhan city. In addition, we should pay more attention to prevent the advanced technology of "virtual into effect" in the introduction of foreign investment, namely in the foreign-owned or joint venture enterprises, even the advanced technology with the advanced production factors flowing into our country, but the boundaries, level of the transferring technology are strictly under control of the foreign investment, which causes our country almost attempt nothing and accomplish nothing in technology development, so we should insist on in the leading industry, pillar industry joint venture, the local capital must occupy a certain proportion firstly; secondly encourage Foreign Company to become shareholder based on advanced technology investment or providing technical support.

\section{Optimizing the structure of foreign investment, promoting the sustainable economic development of Wuhan City}

Wuhan City should actively make use of investment guide to contribute to the restructuring and upgrading of the economic structure. First of all, we should continue to develop high and new technology industry. The development of high-tech industry means that Wuhan will strive for foreign investors identity on the advantage of local resources, through the strengthening of the local advantages, especially by means of combining local advantages of resources and the more advanced external resources to promote the Wuhan industrial upgrading and technological progress to accelerate the building of new industry heights and the transformation of industrial structure in order to form and reinforce Wuhan International Competitiveness in the industry. Wuhan should bring in technology, capital intensive industry with large scale, strong competitiveness and providing breakthroughs such as automobile, petrochemical, machinery manufacturing etc., to implementation the goal of Wuhan City moderate heavy industrialization. Especially we should attract the world's top 500, the internationally renowned enterprises, Multi-National Corporation to set up a manufacturing center and training base, to encourage its regional headquarters and R \& D center to transfer in Wuhan. On one hand, the companies own strong capital, modernization management, and the Multi-National Corporations are based on the long-term development, stable business generally. On the other hand, we should also raise international reputation of Wuhan to lay the foundations for Wuhan market internationalization. At the same time, we should strengthen the introduction of capital and make use of advanced technology and management experience from Europe and America to promote the adjustment of Wuhan City Industrial Structure and product upgrading. Secondly, we should develop modern service industry. This requires Wuhan fully understand and play big city influence in the reproduction process of circulation service in particular, grasp the status and function of high value-added services in the field of social production, know the direction of the development of competitive advantage in the future, make full use of the new pattern of open national service industry after entering WTO, actively promote foreign investment in third industries, make the service industry such as financial industry, logistics 
industry use foreign capital to reach new breakthrough and growth point in utilizing foreign investment.

\section{Seizing the opportunity of foreign investment to the west to fully tap the potential of Wuhan utilizing foreign capital}

In 1987, the provincial government first put forward the slogan "rise of central China", requiring Wuhan play a central role. Wuhan is the first station for foreign capital from the eastern coastal areas to west, the national policy has begun to tilt toward the central and western regions, in the Yangtze River Basin infrastructure investment policy has provided a rare opportunity for Wuhan, it is a key for the foreign capital utilization to make the comparative advantage into competitive advantage, further develop international economic cooperation, remodel of Wuhan mega city statue.

\section{Constantly focusing on improving investment environment of Wuhan City}

In the foreign service, we should strengthen the service function of Foreign Investment Association, constantly improve service and quality according to foreign feedback, and at the same time learn from the coastal area especially Shanghai, Shenzhen, improve work efficiency; give full attention to the role of human capital. On the one hand we should create conditions to attract high-quality personnel who master the operation skills of modern science and technology and market to Wuhan, on the other hand, we should increase input in education, start the different levels of the educational system, train high quality workforce, and focus on cultivate a number of professional talents knowing international economic cooperation and familiar with international rules. In the investment environment we should constantly strengthen in Wuhan manpower advantage; strictly implement the foreign investment access policy, put the using of foreign capital and optimizing the industrial structure together. We should give more preferential conditions to projects optimizing the industrial structure of Wuhan, implement more stringent restrictions on projects developed met market demand on introduction of technology, production capacity etc.. The policy orientation should transfer to deep processing industry and technology intensive projects, especially for the future introduction of electronics, machinery, industrial equipment, strive to transfer to high technology content, high added value project, change the situation dominated by the general processing industry and labor intensive projects; at the same time we also should know if Wuhan want to attract sustainable foreign investment, we must change government function, giving the foreign equal national treatment from the law, not the preferential policy which is short-term, changeable and the immediate interests,

\section{Creating Wuhan brand enterprises and brand products}

In recent years, Wuhan city took measures for foreign enterprises to balance foreign exchange, prompted a considerable portion of foreign investment enterprises to export, made the export of foreign-funded enterprises in the total export share of more and more high. But also we should see, foreign-invested enterprises to export the main force is still some raw materials, product two outside the processing enterprises, and a large number of foreign-funded enterprises are focus on domestic sale. In addition, these enterprises are generally smaller in scale, there is almost no designer foreign enterprises or product burning in Wuhan, and future competition is between big business and designer product, these small enterprises will be at a disadvantage. Although in all economic type in Wuhan City, "three - capital " enterprises benefit is the best, but compared with developed southeast coastal area, benefit is not prominent, so contribution on the Wuhan economic is limited. Therefore, in order to attract foreign direct investment Wuhan City should focus on improving the export competitiveness; adhere to combining research and development of Wuhan City enterprises with the introduction of foreign investment, the introduction of technology and management experience, cultivating core competition capability of the enterprises. To attract more foreign investment in Wuhan in at the same time, we should pay attention to the research and development of their enterprises. We should establish various forms of R\&D center; put the development and promotion 
of science and technology together, strive for designer and fist products from Wuhan, strengthen domestic and international competitiveness.

\section{References}

[1] Cheng Dazhong, Chinese Services and Economic Growth-Study on General Equilibrium Model and Its Empirical [J], The world economy , 2010.10 (In Chinese).

[2] Chen Zhongchang, Ma Hongqi, Study on the Relationship between International Technology Trade and China's Ability of Technological Innovation [J], Research on Industrial Economic, 2010.4(In Chinese).

[3] Pan Helin, Ma Jianping, Chen Qi:,the Empirical Research on the Effects of FDI on Chinese Service Trade " [J], " Statistics and Decision , 2011.23(In Chinese).

[4] Zhang Yuxin, Manufacturing FDI and Services FDI Interaction Mechanism and on China's FDI Enlightenment " [J], " International Business , 2011.96 (In Chinese). 